\title{
New perspectives on not-for-profit financial institutions: Organisational form, performance and governance
}

\author{
Bernardo Bátiz-Lazo* a , Mark Billings ${ }^{\text {b }}$ \\ ${ }^{a}$ Bangor Business School, Bangor University, Bangor, Gwynedd, LL57 2DG, UK \\ ${ }^{\mathrm{b}}$ University of Exeter Business School, University of Exeter, UK
}

The guest editors discuss the context for this special edition, introduce the contributions, consider a number of key themes which link the articles and suggest areas for future research, in particular they make a case for the link of organisational diversity and the stability of the financial system.

Keywords: mutual; proprietary model; not-for-profit financial institutions; financial development; governance; organisational diversity; regulation of financial markets

\section{Introduction}

Mutuals and co-operatives have long been, and remain, of interest to many scholars. Historians are well-equipped to offer insights into the institutional, social, economic, political and geographical contexts in which such organisations operate. 2012 is the United Nations Year of Co-operatives and a forthcoming special edition of Business History will feature articles on co-operatives. This special issue is dedicated to the history of financial institutions established and operated on a not-for-profit basis.

\footnotetext{
* Corresponding author. E-mail: b.batiz-lazo@bangor.ac.uk
} 
There have been many recent contributions to the business history literature on such intermediaries. Pearson's (2010) survey notes the historical importance of mutual organisations in providing various types of insurance service. Murphy's (2010) study of life insurance in the antebellum US includes coverage of mutuals and Wright and Smith (2004) describe and explain the rise and demise of US mutual life insurers. In Britain, chapters in O’Connell (2009) discuss formal and informal co-operative credit and the development of credit unions, a sector that remains very small in most countries. Fear and Wadhwani (2011) contrast savings banks in Germany and the US. McLaughlin $(2009 ; 2011)$ extends the empirical literature on regulatory capture in his examination of Irish microfinance institutions. Guinnane and Martínez-Rodríguez (2011) argue that the co-operative legal form existed in Spain from 1869, earlier than commonly asserted, and that the development of co-operative law was closely tied to the development of company law, which echoes a major theme in the study of UK building societies by Noguchi and Bátiz-Lazo (2010). National and international networks of not-for-profit organisations have been shown to be important in sustaining the sector. Contributions here include that of Menzani and Zamagni (2010), who document the long-standing and continuing importance in the Italian economy of cooperatives both as individual organisations and in networked business groups. In a similar vein, Bátiz-Lazo (2004) and Comín (2007) highlight the role of CECA, the confederation of Spanish savings banks (cajas), in sustaining the collective market share of these banks against commercial banks.

Our chief aim in this special edition is to provide a platform for contributions which extend the literature discussed in the previous paragraph. The selected articles identify organisational forms and practices in need of attention, re-examine wellstudied organisational forms in a different light and move the research agenda forward 
by pointing to promising subject areas. The remainder of this introductory article proceeds as follows. The next section offers our concept of not-for-profit-financial institutions. The third and fourth sections discuss the contents of this special edition. The fifth section briefly discusses a topic worthy of more attention from business historians: the relationship between the recent financial crisis and the reduction in diversity among financial intermediaries. The sixth and final section concludes.

\section{What is a not-for-profit financial institution?}

\section{A first approach}

In broad terms, there are five features that distinguish the non-profit organisation or $\mathrm{NGO}^{1}$ and portray how it exists for the benefit of a specific community (Basri \& Khalid, 2011, p. 4):

a) Organised - there is structure and regularity to the organisation's operations, whether it is formally incorporated or not.

b) Private - the organisation '... is barred from distributing any profits it earns to persons who exercise control over the firm, such as its members, officers, directors or trustees ... a nonprofit firm, by definition has no owners - that is no persons who have a share in both control and residual earnings' (Hansmann, 1996, p. 228).

c) Self-governing - internal governance mechanisms regulate the organisation's behaviour. These can be both defensive and proactive rules and procedures.

d) Voluntary - membership and participation are not legally required or otherwise compulsory. 
e) Transparent and accountable - an organisation has to demonstrate effective use of material and financial resources so that stakeholders can ascertain the force and legitimacy of their claims and judge their impact on society. This feature reflects a complexity in the relationship between the organisation and its stakeholders that goes beyond a purely economic or financial transaction.

In this special edition we are mainly concerned with 'private' features of such organisations, those described by Hansmann (1996, pp. 1-2) as the 'non-investorowned enterprise', with 'patrons' rather than investors. Our emphasis is on organisations involving the deployment of resources ('foundation') rather than of individuals ('association') (Basri \& Khalid, 2011, p. 3). But we consciously set out to go beyond this definition as Hansmann (1996, pp. 242-243) already acknowledges the blurring of these concepts in relation to the provision of financial services.

We use the term 'not-for-profit financial institution' (NFPFI) to refer to actual and potential participants in financial markets whose main purpose is not to make economic profits for distribution to external providers of capital or managers, but to meet other objectives. These include the provision of financial services to particular customer groups not served by other institutions or to provide alternatives which are less expensive, better-suited to the needs of customers or managed in accordance with aims other than profit-maximisation. Such objectives do not preclude the making of accounting profits (or surpluses), but where such profits are made they should be used in a manner consistent with these objectives. This could include distributions to customers or members (who may be the same people, depending on the structure adopted), either in the form of cash, lower prices or a 'social dividend'. 
As financial intermediaries, NFPFIs have been systematically subjected to more intense government regulation than other NGOs. This seeks to protect 'donors' (e.g. retail depositors) and sometimes even dictates the nature of operations (e.g. in trustee-governed savings banks) while aiming for transparency and accountability. The roots of this regulation lay in financial markets permeated by incomplete and asymmetric information. A vast literature explores potential agency problems of conflict of interest and moral hazard in different markets and organisational forms. At its broadest, the agency problem in financial intermediation leads to two types of conflicts of interest: owner-customer, in which the interests of owners may be prioritised over customers, and owner-manager, in which managers indulge in 'expense preference' behaviour or the pursuit of objectives such as growth, size and market share. NFPFIs attempt to internalise the first of these conflicts by making customers the owners, eliminating the incentive for owners to take decisions which would damage customers' economic interests. The second conflict does not arise in the early stages of organisational development when owners are directly involved in management. But as soon as decision-making is delegated to managers, monitoring becomes necessary to ensure efficient management in the wider interest and deter managerial opportunism. This involves costs, thereby undermining the incentive for owners to exercise effective control, a problem frequently argued to be greater in mutual than joint-stock financial institutions, although depositors may prove effective monitors (Hollis \& Sweetman, 2007). Economists such as Diamond (1984) and Casson (1997) stress efficiency in managing information costs, and here the not-forprofit form may offer inherent benefits, such as informational efficiency in the screening and monitoring of lending and underwriting risks and the enforcement of obligations. Such informational advantages can reduce risk, generating trust between 
members and in institutions. Trust may also be generated through links to trusted organisations. It is often argued that mutuals have advantages in dealing with longterm risks subject to greater uncertainty where reliable information is lacking (see, for example, Wright, 2010a, and Wright \& Smith, 2004). But in return, mutuals have to be perceived to be accountable.

Our broad definition of NFPFIs can include organisations legally constituted as 'for-profit', but which are de facto NFPFIs, not expected to make profits, and established for other purposes. On this basis, the term NFPFIs may apply to a wide range of organisations, at least at some point in their development, for example: building societies; friendly societies; mutual or co-operative banks; credit unions; savings banks; community banks; thrifts or building/savings and loan associations; mutual insurers; and stock exchanges. But we acknowledge that a strict definition of 'non-profit' would be limited only to those 'true' non-profits which have no owners and where distributions of surpluses to controlling stakeholders are prohibited.

\section{NFPFIs: Endangered species or the dawn of a new organisational synthesis?}

The philanthropic or charitable origins of many NFPFIs reflect particular economic, social or ideological aims. Many such organisations were founded and operated at a local level on a self-help basis, often to meet the needs of working class, low income, and sometimes immigrant, customers (see, for example, Wadhwani (2002) on the US's first savings bank). Regulation was designed to encourage conservative management and prevent conflicts of interest, while promoting the Victorian virtues of self-improvement and thrift to avoid dependence. These institutions were typically intended to be self-governing and democratic. They often had strong ties to their local communities and/or specific socio-economic, religious or ethnic groups, which helped 
them to overcome the information asymmetries to which all financial intermediaries are subject. ${ }^{3}$ Such factors remain important to some NFPFIs, for example the 'affinity' mutual insurers such as the NFU [National Farmers Union] Mutual and the Police Mutual Assurance Society which still exist in Britain.

Some institutions adopted not-for-profit form for commercial reasons later in their history to overcome potential conflict between shareholders with ownership rights and other stakeholders. Other NFPFIs have emerged from market selfregulation or the need to provide collective services, for example the creation of jointly-owned technology platforms such as Link, Cirrus and Tarjeta 6000 in retail payments and SWIFT in wholesale cross-border payments.

Although NFPFIs have long existed and remain important in many countries, their significance has diminished in other countries in which they were previously more prominent. Many NFPFIs have merged together, mirroring consolidation among other financial institutions. Some NFPFIs have converted to proprietary corporate form, for example through the demutualisation of building societies and insurers in Australia, Britain and New Zealand. For a variety of reasons many NFPFIs have failed, for example many mutual savings and loan associations in the US (Mason, 2004) and the Equitable Life Assurance Company in the UK (O'Brien, 2006). The demutualisation of the largest British building societies has been seen as a response to their inability to grow within the 'movement', hampered by constraints on management recruitment and remuneration arising from societies' traditional reliance on internal labour markets (Klimecki \& Willmott, 2009). With hindsight, it is clear that these conversions shifted into the listed bank sector a number of institutions which appeared to have the management ambition, scale and business skills to survive as listed banks, but in reality lacked some or all of these. 
At least implicitly, all the articles in this special edition revisit the challenge identified by Hansmann (1996): if there is no perfect organisational form then the relative merits of different forms must be subject to evaluation. We take no ideological stance and do not idealise not-for-profit organisational forms as an inevitably and unambiguously preferable alternative. NFPFIs face the same challenge as other business organisations: in the long-run they must perform to the satisfaction of their stakeholders and governance issues must be managed effectively. This will be particularly true in competitive markets in which failure to achieve at least a minimum level of cost-efficiency, or ensure customer experience comparable to that available from for-profit alternatives, would be expected to drive providers out of business. But at the same time, NFPFIs can be associated with unfavourable outcomes in the competitive environment. For instance, the not-for-profit organisational form can create barriers to exit and lead to other problems. Reduced incentives for patrons to monitor effectively may lead to the over-accumulation of capital in inefficient or inefficiently large institutions (Hollis \& Sweetman, 2007). This may in turn generate pressures to demutualise, leading to greater risk-taking and the dissipation of excess capital. Another exit barrier may be reduced market discipline - a non-profit or nondividend-paying institution needs only a relatively low level of profits or surplus to survive.

In summary, NFPFIs can be associated with competitive success and failure. It is the aim of this thematic collection of articles to promote their study, debate what makes them special and gauge their contribution to society. In the words of Sir Winston Churchill: 'Success is not final, failure is not fatal: it is the courage to continue that counts.' 


\section{The articles}

The response to the call for papers for this special edition provided further evidence that the study of NFPFIs is alive and well. There were sufficient proposals to have filled this issue several times over, and our task in making selections was not an easy one. Our objective was not to choose articles which argue for the superiority of a particular institutional form, nor to offer a balanced or comprehensive overview of the sector, but to provide a series of contributions based on original research and/or innovative analysis, which are theoretically informed and explain change over time rather than describing static conditions. Several of the articles are explicitly novel in the choice of subject matter or methodology. Others have benefited from the opening of archives or publication of records, which have presented new opportunities and allowed scholars to generate and address new questions as well as revisit older ones.

This special edition reflects the diversity of both business history and NFPFIs in presenting articles across a range of institutional types, countries and time periods, with different thematic, theoretical, and empirical perspectives. In this section we briefly describe the individual contributions in the sequence in which they are presented. For convenience Table 1 sets out the articles and in the next section we discuss a number of themes which link these articles.

\section{[INSERT TABLE 1 HERE]}

Geographically the articles deal with institutions in Australia, Palestine, Spain, the UK, the US, and a genuinely international institution, SWIFT. There are, of necessity, obvious gaps in our selection - very few of the proposals we received related to the southern hemisphere or developing countries. Several articles are studies of individual institutions, others deal with specific institutional types. These 
range from nineteenth century mutual insurance companies and savings institutions to twenty-first century providers of microcredit and international payments infrastructure. Credit providers of various types are the dominant institutional form and the temporal focus of most of the articles is the twentieth century.

We start with two articles on insurance. In the first of these, O'Brien and Fenn provide evidence on governance practices among mutual life insurers in nineteenth century Britain and compare their performance against proprietary companies. They find that mutuals were larger than proprietary/stock companies and experienced much lower failure rates. As we might anticipate, the success of mutuals was attributable in part to their ability to generate economies of scale. They were able to create a virtuous circle, usually not charging commissions and so able to offer higher returns and attract more policyholders in a period before sophisticated risk management techniques were fully-developed. Managerial diseconomies were kept in check by a broad variety of mechanisms, such as representation through elected members or bodies. This article complements and extends various aspects of insurance history, for example: Pearson's (2002) study of mutuality in eighteenth century fire insurance companies; Alborn's (2009) study, a principal theme of which is the reduction of information asymmetries in life insurance; Johnson's (2010) comparison of the performance of joint-stock and mutual life insurers; and the work on US insurers by Wright (2010a) and Wright and Smith (2004).

The Australian life insurance industry was long dominated by a small number of mutuals. Keneley's detailed study of one of these, the AMP, one of Australia's largest and most enduring business organisations, shows how it moved gradually away from mutuality until its eventual final break through demutualisation. This was no abrupt abandonment of mutuality, rather an evolution in which the professionalisation 
of management, and changes in markets, regulation, technology and the commercial environment gradually shifted it away from its founding principles. Keneley's analysis suggests that demutualisation is the outcome of a complex process and provides a fresh look at a debate that, at least in the UK, was permeated by managerial and political themes (e.g. Barnes, 1984; Kay, 1991; Llewellyn, 1996; Llewellyn and Holmes, 1991). Much of the literature on mutual and co-operative financial institutions stresses their cultural characteristics, as the institutions themselves and their advocates also frequently do. Hansen (2007) analyses the transition of large Danish savings banks into commercial banks, emphasising how this process was influenced by shared historical narratives, which helped to shape their organisational culture and capabilities. Keneley complements this article in demonstrating the same kind of 'cultural shift' in a major Australian mutual.

In the next article, Carbonell examines the development of Barcelona's Montes de Piedad in the eighteenth and nineteenth centuries. These institutions were originally established throughout Europe by the Catholic church as charitable lenders, reliant on donations to fund lending on the security of pledged goods. As in Samy (2001) and Colvin and McLaughlin (2011), Carbonell borrows ideas from the current microfinance debate to explore the emergence of retail financial practices during the first industrial revolution. She shows that there was no single path for amalgamations between individual montes and savings banks while, at the same time, arguing that these charitable institutions acted as a 'buffer' to help prevent individuals resorting to usurers, a role that was particularly important in Barcelona's developing financial system during the economic and financial crisis of 1847-8.

Mason charts the evolution of organisational form in US thrifts from their beginnings in the early nineteenth century to the Great Depression. Different forms 
dominated in different parts of the country and time periods. Eventually, federal regulation, under the powerful influence of commercial banks, forced change, although this was reinforced by pressures from within the 'movement' to professionalise and change organisational form. These changes parallel the developments among US savings banks recently charted in this journal by Wadhwani (2011). Both these studies demonstrate how the public objectives of these organisations led to restrictions on their powers which contributed to their long-term decline in the twentieth century.

Building societies, the British equivalent of the US thrifts, have attracted much less interest from business historians than banks and insurers. But scholars have begun to exploit the archives of building societies and related sources (e.g. Bátiz-Lazo \& Billings, 201x; Noguchi \& Bátiz-Lazo, 2010; Samy, 2011). In contrast to their US counterparts, British building societies enjoyed a remarkable expansion between the World Wars and Scott and Newton examine how a small group of societies emerged to dominate the movement during this period. These societies built scale through organic growth and without resort to financial markets. The authors use the archival records of a number of societies to examine their marketing activity, which they argue generated scale economies which were key to this growth. Their article complements the recent work by Samy (2011), who identifies the principal beneficiaries of these changes as the institutions' managers, who enjoyed relatively high remuneration and public profiles.

Koistinen shows how de facto NFPFIs acted as providers of development capital in the US after World War Two. These development credit corporations (DCCs) were organised state-by-state and were constituted on a 'for-profit' basis, although were never expected to earn significant profits. This was effectively a form 
of surrogate regional policy practised by organisations established and funded by conventional financial institutions in response to political pressures arising from disappointing regional economic performance. They may therefore have pre-empted the type of government intervention which in Britain led to the creation of the institutions which eventually formed 3i (Coopey \& Clarke, 1995; Scott \& Newton, 2007).

Di Martino and Sarsour break new ground for this journal, and business history in general, in presenting an article on Palestine. They examine a microcredit institution (ACAD) in a setting so far almost completely ignored by business and economic historians. Like Carbonell's Montes de Piedad, ACAD has relied on donations to fund its lending activity. In contrast to Carbonell's case, these came from international donors. ACAD's reliance on these donors and high levels of bad debt among its customer base raise the question of whether this institution should be more properly considered a means of distributing aid than a commercial enterprise. In these circumstances the agency problem is different from that of most of the other institutions featured in this issue: it is expected to fulfil an economic development role promoting social inclusion while operating under extreme conditions.

In the final article Scott and Zachariadis examine the development of SWIFT, the international interbank payments organisation, a key infrastructure element in the globalisation of financial markets. Faced with the need for substantial capital investment to secure connectivity, reduce duplication and enforce standards, cooperation was required in the banking community to create and operate a network for collective benefit. This was achieved very successfully through an unusual crossborder not-for-profit organisation in which participants co-operated to produce a standardised solution, a topic addressed recently in this journal in a very different 
context by Velkar (2009). The authors explain how this success came about and address concerns that it has constrained competition and innovation. Their article complements a recent book on the VISA organisation (Stearns, 2011) and Crompton and Jupe's (2007) article on the use of the 'not-for-profit' form in providing critical infrastructure in Britain's privatised railway system. In firmly connecting business history to the sociology of finance and the history of technology they also extend the international business history of financial institutions beyond the well-known perspectives of the self-standing company (Wilkins \& Schröter, 1998) and banks as multinational corporations (Jones, 1993).

\section{Article themes}

A number of common, often overlapping, themes emerge from the very different articles presented. Some of these may be 'old' themes, but can appear in a new perspective when placed in an international and comparative context.

Unsurprisingly, governance is one of the key themes. Business historians have been very active in recent years in exploring the diversity and complexity of corporate governance (notable contributions include, for example: Cheffins, 2008; Hannah, 2007a, 2007b; Wright \& Sylla, 2011). The articles included here provide welcome insights outside the narrow range of enterprise governance arrangements in large listed companies, beyond which Herrigel (2007, pp. 481-482) encouraged scholars to venture.

O'Brien and Fenn illustrate the diversity of governance arrangements among nineteenth century British mutual insurers. Keneley's longitudinal study of the evolution of mutuality in the AMP addresses from a different perspective the question 
of how mutual insurance models vary from company to company and over time. Both articles deal with the rights to residual profits and control, key aspects of mutual governance. In several contributions (Carbonell; Di Martino \& Sarsour; Keneley) the presence of many stakeholder groups led to a confusion of objectives, which is no surprise as the question of accountability in NFPFIs is a long-standing one. In the AMP, which offered some products which did not confer membership or were dependent on the performance of the assets in which funds were invested, the contradictory interests of different customer groups ultimately contributed to demutualisation. In ACAD, the potential conflict between commercial and development aims appears not yet to be resolved. In several articles (Keneley; Mason; O'Brien \& Fenn; Scott \& Zachariadis) there is evident tension between the professionalisation of management, inevitable as institutions grow, and the ownermanager agency problem which exists in both mutual and proprietary companies.

In several articles (Carbonell; Di Martino \& Sarsour; Keneley) the organisations have at least some religious connection. As in Colvin (2011), confessional orientation can act as a screening and monitoring device to cope with moral hazard and reduce risk faced by a lender or insurer. The importance of overcoming asymmetric information problems in order to manage risk effectively is a challenge for all financial institutions, and is addressed in other recent scholarship on NFPFIs. In part of a wider project, Guinnane and Streb (2011) address moral hazard in nineteenth century German insurance/benefit societies where small organisational size and members' personal knowledge conferred informational advantages. Gottleib (2007) and Murray (2007) studied US industrial sickness funds/insurance societies, finding that they enjoyed informational advantages in handling adverse selection and 
moral hazard issues, arguably at the expense of wider access, until regulators repressed them during the Great Depression.

In Keneley's AMP and Mason's thrifts, changes in regulation hastened the transformation or demise of institutions founded and developed as NFPFIs. This is not a new theme: Hansmann (1996, p. 5) noted that 'governmental consumer protection regulation has often played a critical role in permitting investor-owned enterprise to vie with, and ultimately displace, cooperative, mutual, and nonprofit firms'.

Much discussion on NFPFIs focuses on their reliance on retained profits as their principal source of capital, with limited, or in some cases no, access to external capital markets. Viswanathan and Cummins (2003) identified the need to raise capital as crucial in US insurance demutualisations in the 1980s and 1990s. Michie (2011, pp. 313, 315-317) has criticised the post-financial crisis attitude of UK regulators to the inability of NFPFIs to raise external capital as one of the features of 'pro-plc' regulation. But the evidence presented here suggests that this problem can be overcome where regulation and the imagination of 'patrons' permit. In several articles NFPFIs used alternative mechanisms for raising capital: donations (Carbonell; Di Martino \& Sarsour); equity and debt provided as a result of political pressures (Koistinen); various methods among mutual insurers (O’Brien \& Fenn); and levies on the organisation's members (Scott \& Zachariadis).

The notion that NFPFIs create public goods is common to several articles. This was recognised by 'patrons', who provided capital, expertise or both, in the belief that the organisations studied represented a social response to market problems. The nature of these public goods varied considerably. Often this was the promotion of thrift in different contexts and by different means (Carbonell; Keneley; Mason; 
O'Brien \& Fenn; Scott \& Newton). For the DCCs the contribution was to promote business growth in local economies, complementing the activities of the conventional lending institutions which were the DCCs' financial sponsors, as well as forestalling unwelcome political interventions (Koistinen). In SWIFT's case, the public good was a technological network which supported an explosion in transaction numbers (Scott \& Zachariadis).

Carbonell's Montes de Piedad and Di Martino and Sarsour's ACAD contribute to economic development, emerging to fill gaps in the provision of finance. These are microcredit institutions, often seen as a form of socially responsible investment with financial values reinforcing social and cultural values. Advances in microcredit, and microfinance more widely, have been hailed in recent years, but have long historical antecedents. Microfinance's growing maturity in some countries but absence from others can be puzzling; for example, Moyo's (2009) controversial and fierce critique of international aid notes the absence of microfinance institutions from most African countries. Microfinance is under attack in countries where it has been prominent recently: Bangladesh and India. In the former, doubts have emerged over its lasting impact, and in the latter commercial providers, with the clear profit motive also typical in Latin America, have been attacked for charging interest rates which have made repayment difficult, although these rates may have been lower than those available from alternative sources. Such issues raise potentially interesting questions for business historians, but must be dealt with elsewhere.

Another broad theme is that of innovation and entrepreneurship in meeting customer needs, developing and marketing new products and services, and in management and the deployment of technology as the basis for increasing organisational effectiveness, allowing NFPFIs to meet their objectives. All the 
contributions feature some form of innovation. This is perhaps most obvious in the articles by Keneley and Scott and Zachariadis, whose organisations harnessed the information technologies of the third industrial revolution (Galambos, 2005). Carbonell's Montes de Piedad, Di Martino and Sarsour's ACAD, Mason's thrifts and Koistinen's DCCs all demonstrated innovation in developing their services, echoing the theme of innovation in catering to the needs of small savers recently explored by Maixé-Altés (2009) and Wadhwani (2011). O’Brien and Fenn's insurers innovated in the evaluation and management of risk, and Scott and Newton's building societies in marketing.

Several of the contributions explore the boundaries between NFPFIs and forprofit institutions, with whom they have competed, or whose services they have complemented, or for whom they have provided services. The dividing line between 'for-profit' and 'not-for-profit' financial institutions is less neat than legal form would imply and NFPFIs are not always as they may appear, as evidenced in the Lancashire terminating building societies investigated by Hart (2009). Koistinen's DCCs were constituted as for-profit companies but no returns were expected. In contrast Keneley's AMP was formed as a friendly society and eventually surrendered mutual form having concluded that this was incompatible with the changing environment in which it was operating. Di Martino and Sarsour's ACAD, as we have noted, is an unusual institution in that its reliance on donations has apparently freed it from the need to generate profits or surpluses, but forced it to rely on donors.

Finally, the Chandlerian concepts of critical scale and organisational capabilities (Chandler, 1962; 1977; 1990) are relevant to several articles, raising the frequently-asked question of the relationship between size and success (O'Brien \& Fenn; Scott \& Newton). The articles by Mason and Scott \& Newton deal with the 
transformation of local or regional organisations into national organisations. But size alone is insufficient to ensure success and can create its own problems, as Keneley's study suggests.

\section{NFPFIs, organisational diversity and the study of financial crises}

Before concluding this introduction we would like to comment on the role of NFPFIs in the financial crisis of the late 2000s. There is a widely-held view that financial institutions owned by private shareholders rank amongst the most culpable in the recent financial debacle and that alternative forms of governance and ownership could contribute to superior long-term outcomes. Wright (2007) anticipated this debate, arguing that efficiency is not so much a function of ownership as it is of market structure (the more competitive the more efficient) and internal incentive alignment (the closer the more efficient). ${ }^{4}$ However, in spite of the continuing interest in the historical study of NFPFIs the latter were absent from recent special editions on financial crisis by business historians (Hansen, 2009; Kobrak \& Wilkins, 2011) and even within the discourse of historians targeting the wider general public (e.g. Ferguson, 2009; Marichal, 2010).

The case for mutuals, not only in financial services, is robustly reiterated by Michie (2011), who draws on evidence from many countries. Joint-stock companies have converted to mutuals before and Michie and Llewellyn (2010) proposed the remutualisation of failed institutions such as Northern Rock (although at the time of writing it appears that the UK government will divest itself of ownership via a more conventional route of privatisation). Along similar lines, Co-operatives UK (2011) has proposed that the British post office, an important provider of financial services, 
particularly to lower income groups, could be privatised as a mutual, arguing that this would be the most appropriate organisational form to support public service delivery. Supporters of such moves promote them on the basis of greater transparency and increasing accountability to stakeholders. However, British mutual building societies and the Spanish cajas have consolidated further, with both sectors continuing to shrink and increasing in concentration. Indeed, the cajas have been forced to raise capital through stock market flotations (a move in which the International Monetary Fund seems to have played an important role in advising the Spanish government).

The inadequacies of regulation, which both failed to prevent financial crisis and contributed to reduced diversity among financial institutions, strengthen the case for encouraging greater diversity. Indeed, as several of the articles in this issue and various other authors (Hansmann, 1996; Murray, 2007; Wadhwani, 2011; Wright, 2010a) argue, regulation has contributed to the long-term decline of NFPFIs.

But regulatory change is not solely responsible for the loss of organisational diversity. Market forces are at work here too as seen in the broader debate on financialisation, in which many of the contributions question the nature of financial systems and institutions (Dore, 2008; Epstein, 2005). One of the symptoms of financialisation has been the move of non-financial organisations to offer financial products and services whose accounting profitability exceeds that in core markets (see Bátiz-Lazo and Reese (2010) and references therein). This has contributed to a homogenisation of organisational forms which has reduced diversity, thereby weakening the 'ecology' of the financial system. Efforts to regenerate greater variety and complexity in organisational form might therefore contribute to a more robust financial system (Centre for Research on Socio Cultural Change, 2010; World Economic Forum, 2010). It is therefore argued that a strong mutual sector could 
underpin enhanced financial stability and invigorate retail financial services: 'Different business models will drive innovation and competition' claims Michie (2011, p. 313).

These arguments have led to expressions of political support for mutuality. In the UK, for example, government proposals for strengthening the financial system envisaged a greater role for a mutually-owned financial sector (HM Treasury, 2009; 2010). Statements by George Osborne, the Chancellor of the Exchequer (Finch, 2009), Lord Turner, chairman of the Financial Services Authority (BSA, 2010a), and Vincent Cable, the Business Secretary (BSA, 2010b), advocated a greater variety in the organisational ecology of the UK financial system. In Brazil, the central bank has given serious thought to the issue (da Silva, 2011). So far, in Britain at least, this has not translated into practical steps to bring 'parity of esteem' for mutual and proprietary models and equality of treatment in regulation and supervision. Some argue that this is because British regulators take the proprietary model as the norm and regard mutuals as a 'deviation' (Mutuo, 2010, pp. 6, 13).

In summary, there has been a loss of diversity in the organisational ecology of financial markets and this has been identified as one of the reasons for the acute nature of the financial crisis of the late 2000s. Mutuality of itself, of course, does not prevent problems in the financial sector but there is an opportunity for historians to contribute to this debate by providing empirical evidence which links organisational diversity, alternative forms of corporate governance and financial instability.

\section{Conclusions}


Business history is sometimes criticised for focusing too heavily on successes. Although most of the organisations investigated in this special edition can be considered successful in some way, this is not true of all of them for all of their history. The articles therefore provide insights into the conditions in which the notfor-profit organisational form may function well in the provision of financial services and how NFPFIs evolve to reflect the needs of the stakeholders and societies they serve. In particular, such institutions are likely to be most successful when they have a clear purpose, although this may evolve over time, and may be compromised by the diversity of interests among stakeholder groups.

We have already noted the reduction in institutional diversity in the context of our discussion of financial crisis. If we view crisis as at least in part a manifestation of the impact of long-term changes in the financial system, historians and other scholars should evaluate the relative performance of not-for-profit and joint-stock financial institutions in the years ahead of, and during, the financial crisis of the late 2000s. Inevitably governance will remain a rich field for historians and non-historians alike, and it will be important to investigate managerial behaviour, such as managers' attitudes to risk-taking opportunities and the rewards for risk-taking. But lack of archival access may constrain such research and suggest other approaches.

At a basic level, this special edition has provided a platform for theoretically informed studies of NFPFIs grounded in the wider business history literature, addressing 'the main aim of business history ... to study and explain the behaviour of the firm over long periods of time, and place the conclusions in a broader framework of the markets and institutions in which that behaviour occurs' (Wilson, 1995, p. 1). But in our view these articles go beyond this and collectively deal with 'big themes' such as the novelty of microfinance, demutualisation, comparative performance with 
proprietary models, the role of NFPFIs in economic development, and the role of information technology, and thereby 'provide a dynamic insight into the evolution of capitalism, bringing a comparative element to the field which can draw on material from firms, industries or national groupings of businessmen' (Wilson, 1995, pp. 1-2). To paraphrase Mark Twain, 'reports of the death of the non-profit have been greatly exaggerated'. We hope you enjoy reading this stimulating and varied collection of articles.

\section{Acknowledgements}

We thank the executive editors, Stephen Diacon, Jonathan Michie, Robert E. Wright, and the many reviewers who provided rigorous and helpful critiques of the contributions.

\section{Notes on contributors}

Bernardo Bátiz-Lazo is Professor of Business History and Bank Management at Bangor University and Mark Billings is Senior Lecturer in Accounting at the University of Exeter Business School.

\section{References}

Alborn, T.L. (2009). Regulated lives: Life insurance and British society, 1800-1914. Toronto: University of Toronto Press.

Barnes, P. (1984). Building Societies: The myth of mutuality. London: Pluto Press. 
Basri, H. and Khalid, S.N.A. (2011). Strengthening accountability of charitable organisations: A literature review. Academic Public Studies Archive (http://EconPapers.repec.org/RePEc:nsu:apasro:312 accessed 29 July 2011).

Bátiz-Lazo, B. (2004). Strategic alliances and competitive edge: Insights from Spanish and UK banking histories. Business History, 46, 23-56.

Bátiz-Lazo, B. \& Billings, M. (201x). Accounting regulation and management discretion - a case note. Abacus, forthcoming.

Bátiz-Lazo, B. \& Reese, C. (2010). Is the future of the ATM past? In A. Kyrtsis (Ed.) Financial markets and organizational technologies: System architectures, practices and risks in the era of deregulation (pp. 137-165). Basingstoke: Palgrave-Macmillan.

BSA (2010a). Building societies do not need to re-regulate. Building Societies Association (http://www.bsa.org.uk/feature/fsacomment.htm; accessed 26 July 2011).

BSA (2010b). Northern Rock could be remutualised. Building Societies Association (http://www.bsa.org.uk/feature/nr_vince_cable.htm; accessed 26 July 2011).

Casson, M. (1997). Institutional economics and business history: A way forward? Business History, 39, 151-171.

Centre for Research on Socio Cultural Change. (2010). An alternative report on UK banking reform. Manchester: CRESC.

Chandler, A.D. Jr. (1962). Strategy and structure: Chapters in the history of the American industrial enterprise. Cambridge, MA: MIT Press.

Chandler, A.D. Jr. (1977). The Visible Hand: The Managerial Revolution in American business. Cambridge, MA: Harvard University Press. 
Chandler, A.D. Jr. (1990). Scale and scope: The dynamics of industrial capitalism. Cambridge, MA: Harvard University Press.

Cheffins, B. (2008). Corporate ownership and control: British business transformed. Oxford: Oxford University Press.

Colvin, C.L. (2011). Religion, competition and liability: Dutch cooperative banking in crisis, 1919-1927. Unpublished PhD Thesis, Department of Economic History, London School of Economics and Political Science.

Colvin, C.L. \& McLaughlin, E. (2011). Raiffeisenism abroad: Why did German microfinance fail in Ireland, but prosper in the Netherlands? Paper at European Historical Economics Society Annual Conference, Dublin.

Comín, F. (2007). Spanish savings banks and the competitive cooperative model (1928-2002). Revista de Historia Económica, 25, 199-230.

Co-operatives UK. (2011). Mutual options for the Post Office Ltd. Manchester: Cooperatives UK.

Coopey, R. \& Clarke, D. (1995). 3i: Fifty years of investing in industry. Oxford: Oxford University Press.

Crompton, G. \& Jupe, R. (2007). Network Rail - forward or backward? Not-for-profit in British transport. Business History, 49, 908-928.

Da Silva, M. A. (2011). Impactio do sistema coopeativo de crédito na eficiência do sistema financier nacional. Trabalhos para Discussão 246. Banco do Brasil (http://d.repec.org/n?u=RePEc:bcb:wpaper:246\&r=his accessed August 30, 2011).

Diamond, D. (1984). Financial intermediation and delegated monitoring. Review of Economic Studies, 51, 393-414. 
Dore, R. (2008). Financialization of the global economy. Industrial and Corporate Change, 17, 1097-1112.

Epstein, G.A. (2005). Financialization and the world economy. Cheltenham: Edward Elgar.

Fear, J. \& Wadhwani, R.D. (2011). Populism and political entrepreneurship: The univerisalization of German savings banks and the decline of American savings banks, 1907-1934. In H. Berghoff, J. Kocka \& D. Ziegler (Eds.), Doing business in the age of extremes: Essays in the economic history of Germany and Austria in memoriam Gerald Feldman (pp. xx-xx). Cambridge: Cambridge University Press.

Ferguson, N. (2009). The ascent of money. London: Penguin.

Finch, J. (2009). Small lenders must unite to relieve mutual distress. The Guardian, June 11, 2009.

Galambos, L. (2005). Recasting the organizational synthesis: Structure and process in the twentieth and twenty-first centuries. Business History Review, 79, 1-38.

Gottleib, D. (2007). Asymmetric information in the late nineteenth century cooperative insurance societies. Explorations in Economic History, 44, 270292.

Guinnane, T.W. (1997). Regional organizations in the German cooperative banking system in the late 19th century. Research in Economics, 51, 251-274.

Guinnane, T.W. (2001). Cooperatives as information machines: German rural credit cooperatives, 1883-1914. Journal of Economic History, 61, 366-389.

Guinnane, T.W. (2003). 'A friend and advisor': External auditing and confidence in Germany's credit cooperatives, 1889-1914. Business History Review, 77, 235264. 
Guinnane, T.W. \& Martínez-Rodríguez, S. (2011). Cooperatives before cooperative law: business law and cooperatives in Spain, 1869-1931. Revista de Historia Económica, 29, 67-93.

Guinnane, T.W. \& Streb, J. (2011). Moral hazard in a mutual health insurance system: German Knappschaften, 1867-1914. Journal of Economic History, 71, 70-104.

Hannah, L. (2007a). The 'divorce' of ownership from control from 1900 onwards: Recalibrating imagined global trends. Business History, 49, 404-438.

Hannah, L. (2007b). Pioneering modern corporate governance: A view from London in 1900. Enterprise and Society, 8, 642-686.

Hansen, P.H. (2007). Organizational culture and organizational change: The transformation of savings banks in Denmark, 1965-1990. Enterprise and Society, 8, 920-953.

Hansen, P. H. (2009). Introduction to special issue on scandals and panics. Business History Review, 83, 1-7.

Hansmann, H. (1996). The ownership of enterprise. Cambridge, MA: Harvard University Press.

Hart, R. (2009). Weavers of profit: Terminating building societies in Lancashire, 1780-1840. Financial History Review, 16, 27-45.

HM Treasury. (2009). Reforming financial markets. London: TSO.

HM Treasury. (2010). Building society capital and related issues: A discussion paper. Available at: http://www.hmtreasury.gov.uk/d/consult_buildingsoc_capital.pdf; (accessed 1 August 2011).

Herrigel, G. (2007). Guest editor's introduction: A new wave in the history of corporate governance. Enterprise and Society, 8, 475-488. 
Hollis, A. \& Sweetman, A. (2007). The role of local depositors in controlling expenses in small-scale financial intermediation: An empirical analysis. Economica, 74, 713-735.

Johnson, P. (2010). Making the market: Victorian origins of corporate capitalism. Cambridge: Cambridge University Press.

Jones, G. (1993). British multinational banking 1830-1990. Oxford: Oxford University Press.

Kay, J. (1991). The economics of mutuality. Annals of Public and Co-operative Economics, 62, 309-317.

Klimecki, R. \& Willmott, H. (2009). From demutualisation to meltdown: A tale of two wannabe banks. Critical Perspectives on International Business, 5, 120140.

Kobrak, C. \& Wilkins, M. (2011). The '2008 crisis' in an economic history perspective: Looking at the twentieth century. Business History, 53, 175-192.

Llewellyn, D. (1996). Some reflections on the mutuality v. conversion debate. Journal of Co-operative Studies, 29, 57-71.

Llewellyn, D. \& Holmes, M. (1991). In defence of mutuality: a redress to an emerging conventional wisdom. Annals of Public and Co-operative Economics, 62, 319-354.

McLaughlin, E. (2009). Microfinance institutions in nineteenth century Ireland. 2 vols. Unpublished PhD thesis, National University of Ireland Maynooth.

McLaughlin, E. (2011). Tracing regulatory capture in microfinance: Loan fund societies and the Loan Fund Board in Ireland, 1860-1914. mimeo. 
Maixé-Altés, J.C. (2009). Enterprise and philanthropy: The dilemma of Scottish savings banks in the late nineteenth century. Accounting, Business and Financial History, 19, 39-59.

Marichal, C. (2010). Nueva historia de las grandes crisis financieras: Una perspectiva global, 1873-2008. Editorial Debate: Buenos Aires and Barcelona.

Mason, D.L. (2004). From buildings and loans to bail-outs: A history of the American savings and loan industry, 1831-1995. Cambridge: Cambridge University Press.

Menzani, T. \& Zamagni, V. (2010). Cooperative networks in the Italian economy. Enterprise and Society, 11, 98-127.

Michie, J. (2011). Promoting corporate diversity in the financial services sector. Policy Studies, 32, 309-323.

Michie, J. \& Llewellyn, D.T. (2010). Converting failed financial institutions into mutual organisations. Journal of Social Entrepreneurship, 1, 146-170.

Moyo, D. (2009). Dead aid: Why aid is not working and how there is another way for Africa. London: Allen Lane.

Murphy, S.A. (2010). Investing in life: Insurance in antebellum America. Baltimore, MD: Johns Hopkins University Press.

Murray, J.E. (2007). Origins of American health insurance: A history of industrial sickness funds. New Haven, Conn. and London: Yale University Press.

Mutuo (2010). The mutual manifesto 2010. London: Mutuo.

Noguchi, M. \& Bátiz-Lazo, B. (2010). The auditors' reporting duty on internal control: The case of building societies, 1956-1960. Accounting, Business and Financial History, 20, 41-66. 
O'Brien, C. (2006). The downfall of Equitable Life in the United Kingdom: The mismatch of strategy and risk management. Risk Management and Insurance Review, 9, 189-204.

O'Connell, S. (2009). Credit and community: Working-class debt in the UK since 1880. Oxford: Oxford University Press.

Pearson, R. (2002). Mutuality tested: The rise and fall of mutual fire insurance offices in eighteenth-century London. Business History, 44, pp. 1-28.

Pearson, R. (2010). Introduction: Towards an international history of insurance. In R. Pearson (Ed.), The development of international insurance (pp. 1-23). London: Pickering \& Chatto.

Samy, L. (2011). 'The paradox of success': The effect of growth, competition and managerial self-interest on building society risk-taking and market structure c. 1880-1939. University of Oxford, Discussion Papers in Economic and Social History, No. 86.

Scott, P. \& Newton, L. (2007). Jealous monopolists? British banks and responses to the Macmillan Gap during the 1930s. Enterprise and Society, 8, 881-919.

Stearns, D. (2011). Electronic value exchange: Origins of the VISA electronic payments system. London: Springer.

Velkar, A. (2009). Transactions, standardisation and competition: Establishing uniform sizes in the British wire industry c. 1880. Business History, 51, 222247.

Viswanathan, K.S. \& Cummins, J.D. (2003). Ownership structure changes in the insurance industry: An analysis of demutualization. Journal of Risk and Insurance, 70, 401-437. 
Wadhwani, R.D. (2002). Banking from the bottom up: The case of migrant savers at the Philadelphia Saving Fund Society during the late nineteenth century. Financial History Review, 9, 41-63.

Wadhwani, R.D. (2011). Organisational form and industry emergence: Mutual and nonprofit firms in the development of the US personal finance industry. Business History, 53, xx-xx.

Wilkins, M. \& Schröter, H.G. (Eds.) (1998). The free-standing company in the world economy, 1836-1996. Oxford: Oxford University Press.

Wilson, J.F. (1995). British business history, 1720-1994. Manchester: Manchester University Press.

World Economic Forum (2010). Rethinking risk management in financial services: Practices from other domains. New York: World Economic Forum.

Wright, R.E. (2007). On the economic efficiency of organizations: Toward a solution of the efficient government enterprise paradox. Essays in Economic and Business History, 25, 143-54.

Wright, R.E. (2010a). Insuring America: Market, intermediated, and government risk management since 1790. In L. Caruana (Ed.), Encuentro Internacional Sobre la Historia del Seguro (pp. 239-298). Madrid: Fundacion MAPFRE.

Wright, R.E. (2010b). Thinking beyond the public company. McKinsey Quarterly, September.

http://www.mckinseyquarterly.com/Organization/Strategic_Organization/Thin king_beyond the_public_company_2665, accessed 25 August 2011).

Wright, R.E. and Smith, G.D. (2004). Mutually beneficial: The Guardian and life insurance in America. New York: New York University Press. 
Wright, R.E. and Sylla, R. (2011). Corporate governance and stockholder/stakeholder activism in the United States, 1790-1860: New data and perspectives. In J. Koppell (Ed.), Origins of shareholder advocacy (pp. 231-251). New York: Palgrave Macmillan. 
Table 1. Contents of this special edition.

\begin{tabular}{|c|c|}
\hline Author(s) & Title of article \\
\hline O’Brien and Fenn & $\begin{array}{c}\text { Mutual life insurers: Origins and performance in pre-1900 } \\
\text { Britain }\end{array}$ \\
\hline Keneley & $\begin{array}{c}\text { The path to Project Darwin: The evolution of the AMP's } \\
\text { organisational structure }\end{array}$ \\
\hline Carbonell-Esteller & $\begin{array}{l}\text { Montes de piedad and savings banks as microfinance } \\
\text { institutions on the periphery of the financial system of mid-19th } \\
\text { century Barcelona }\end{array}$ \\
\hline Mason & $\begin{array}{l}\text { The rise and fall of the Co-operative Spirit: The evolution of } \\
\text { organisational structures in American thrifts, 1831-1939 }\end{array}$ \\
\hline Scott and Newton & $\begin{array}{l}\text { Advertising, promotion, and the rise of a national building } \\
\text { society movement in interwar Britain }\end{array}$ \\
\hline Koistinen & $\begin{array}{l}\text { Development credit corporations: Not-for-profit development } \\
\text { finance institutions in the postwar United States }\end{array}$ \\
\hline $\begin{array}{l}\text { Di Martino and } \\
\text { Sarsour }\end{array}$ & $\begin{array}{l}\text { Microcredit in modern Palestine (1995-2008): A business } \\
\text { history perspective }\end{array}$ \\
\hline $\begin{array}{l}\text { Scott and } \\
\text { Zachariadis }\end{array}$ & Origins and development of SWIFT, 1973-2009 \\
\hline
\end{tabular}




\section{Notes}

${ }^{1}$ Basri and Khalid (2011, p. 3) note that numerous terms are used to describe nonprofit organisations including independent, third sector, voluntary, charitable, philanthropic, social, public, faith-based, tax-exempt, non-governmental or civil society.

${ }^{2}$ Across Europe many NFPFIs use retained earnings to fund social activities within their communities. This brings them closer to the character of NGOs than tradebased, for-profit, commercial organisations. Although quite diverse in nature, these expenditures have a positive impact on society and thus provide legitimacy for the organisations' continued existence and operations.

${ }^{3}$ Information asymmetries of two sorts impact on financial institutions: on the one hand, savers are uncertain about whether managers have adequate skills to ensure the security of their funds and, on the other hand, institutions are uncertain about the ability of borrowers to repay. In a series of articles, Guinnane $(1997 ; 2001 ; 2003)$ documented how German credit co-operatives addressed such problems. The challenges to the individual institution of 'effectively managing its activities and communicating to outsiders that it is, in fact, well run' (Guinnane, 2003, p. 235) were met by reliance on internal labour markets to develop local managers, able to forge long-term customer relationships. These were augmented by regional banks to offset liquidity problems and regional auditing associations to monitor management to enhance public confidence.

${ }^{4}$ Wright (2010b) exposes these arguments to a wider audience. 